\title{
Uptake of sub-micrometre- and micrometre-sized detrital particles by bacterivorous and omnivorous ciliates
}

\author{
Thomas Posch*, Hartmut Arndt** \\ Institute of Limnology, Austrian Academy of Sciences, A-5310 Mondsee, Austria
}

\begin{abstract}
We used a new model type of detritus to observe and quantify the uptake of detrital particles by bacterivorous and omnivorous ciliates. It consisted of freshly prepared, fluorescently labeled dead organic particles. To represent autochthonous dead organic matter we chose the diatom Cyclotella meneghiniana, the green algae Monoraphidium minutum and Scenedesmus acutus, the copepod Cyclops abyssorum praealpinus and leaves of the macrophyte Elodea canadensis. Leaves of the copper beech Fagus sylvatica and grass stalks of Poa annua were considered as allochthonous detritus. The different types of organic matter were stained with the fluorescent dye DTAF and artificially disrupted to produce 7 different kinds of fluorescently labeled detritus (FLD) with a size spectrum of 0.2 to $20 \mu \mathrm{m}$ (depending on the organic material we used). The uptake of 6 different kinds of FLD by the ciliates Dexiostoma campylum and Paramecium caudatum was demonstrated. Furthermore, a size dependent uptake of FLD was observed for the ciliate $D$. campylum and ciliates of the Stylonychia mytilus complex. Our study suggests that fine particulate detritus can be an additional food source besides bacteria or other picoplankton in the pelagic zone of lakes. This may increase the complexity of microbial food webs as well as the decomposition rate of particulate detritus.
\end{abstract}

KEY WORDS: Ciliates Feeding Detritivory Detritus Protozod Sub-micrometre particles

\section{INTRODUCTION}

Detritus has generally been considered only as a part of the decomposer food chain parallel to the grazing food chain. The idea of the present study was to investigate whether or not detritus can be incorporated directly into the microbial food web by suspensionfeeding ciliates. In particular, sub-micrometre- and micrometre-sized detrital particles seem to be an important part of dead particulate organic matter (POM) in aquatic ecosystems (Lenz 1972, Wotton 1984,

Present addresses:

- Institute of Zoology and Limnology, University of Innsbruck, Technikerstr. 25, A-6020 Innsbruck, Austria.

E-mail: thomas.posch@uibk.ac.at

- Institute of Ecology, University of Greifswald, Schwedenhagen 6, D-18565 Kloster/Hiddensee, Germany
Georgi 1985). According to Koike et al. (1990), the abundance of sub-micrometre particles $(0.36$ to $1.0 \mu \mathrm{m})$ in the ocean is often higher than the abundance of bacteria. In lakes sub-micrometre particles in the size range 0.2 to $0.7 \mu \mathrm{m}$ can represent 3 to $30 \%$ of what has been considered as dissolved organic matter (DOM) (Middelboe \& Sondergaard 1995). These particles have often been neglected due to the use of GF/F filters for measuring DOM. Sub-micrometre particles can partly pass this type of filter, although they do not really belong to the dissolved fraction of organic material (Søndergaard \& Middelboe 1993). Besides the submicrometre particles there is a large pool of dead organic matter in the size range of a few $\mu \mathrm{m}$ (Lenz 1972, Georgi 1985, Melack 1985 and references therein).

As laboratory studies have shown, the autochthonous and allochthonous origin of these particles as well 


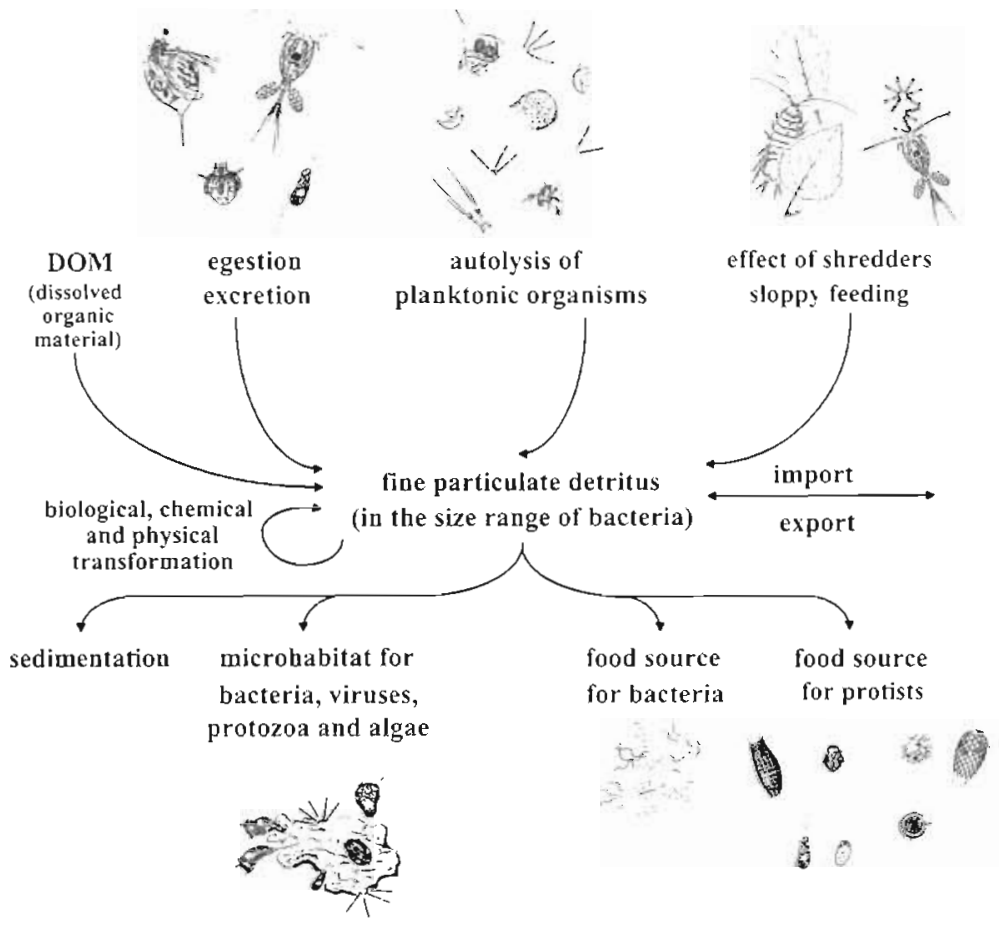

Fig. 1 Possible mechanisms for the formation and transformation of submicrometre- and micrometre-sized detrital particles and their importance as a habitat and a food source in the microbial food web attractive food source for flagellates and ciliates. However, it is not clear yet if the smallest size class of detrital particles (sub-micrometre) is also colonized by microbes.

Although detritivory is often reported to occur among protozoa (Kahl 1930-1935 Sandon 1932, Gast 1985, Fenchel 1987. Sherr \& Sherr 1992) there are nearly no data available on the quality and quantity of the dead organic material protozoa can ingest. This is astonishing because there is a large pool of fine particulate detritus in the pelagic zone, which ciliates and flagellates should be able to graze upon. It is well known that many ciliates (Fenchel 1980, 1986) and flagellates (Marchant \& Scott 1993) ingest pico-sized and even smaller particles such as colloids (Sherr 1988, Tranvik et al. 1993) and viruses (González \& Suttle 1993). In this study we investigated the direct uptake of non-colonized particles by ciliates. Different kinds of fluorescently labeled detritus (FLD) originating from algae, plants, macrophytes and zooplankton were tested as a potential food source for suspension-feeding ciliate species.

\section{MATERIALS AND METHODS} responsible for the formation of this kind of detritus are very complex (Fig. 1): (1) Particle formation out of dissolved organic matter by air bubbles (Johnson \& Cooke 1980) or by aggregation of dissolved compounds to and onto detrital particles of every size range (Kepkay 1994). (2) Formation of fragile, fine particulate detritus in the size range of picoplankton by egestion and excretion. This was shown for phytoplankton (Passow \& Alldredge 1994), for flagellates (Elbrächter 1991), for ciliates (Stoecker 1984) and also for cladocerans (Kersting \& Holterman 1973, Lampert 1978, Olsen et al. 1986). (3) Particle formation by autolysis of small planktonic organisms caused by senescence or parasitism (e.g. by viruses; Suttle et al. 1990). (4) Fun mation of particies by feeding processes (shredding, sloppy feeding; Lampert 1978). The particle spectrum itself is continuously transformed by physical, chemical and biological processes (Wotton 1984). Furthermore, detrital particles with a diameter of several $\mu \mathrm{m}$ and larger provide a potential microhabitat for colonizing bacteria and protozoa (Fenchel 1970, Silver et al. 1984, Grossart \& Simon 1993). Even very small detrital particles in the size range of only a few $\mu \mathrm{m}$ are important substrates for attached bacteria (Pedrós-Alió \& Brock 1983) and may in this way become a more
Cultivation of ciliates. All batch cultures were kept at a temperature of $20^{\circ} \mathrm{C}$ and in continuous dim light. The hymenostome ciliate species Dexiostoma campylum (syn. Colpidium campylum; see Ganner \& Foissner 1989) and Paramecium cáudatum were cultivated in $10 \mathrm{ml}$ glass tubes and fed with bacteria growing on wheat grains. As cultivation medium we used $0.2 \mu \mathrm{m}$ prefiltered autoclaved tap water. Cultures of $D$. campylum were kindly provided by M. Macek (Institute of Hydrobiology, Czech Academy of Sciences, Ceské Budéjovice). $P$. caudatum and hypotrich ciliates of the Stylonychia mytilus complex were isolated from a cuiture of the isopod Asellus aquaticus cultivated at the Institute of Limnology in Mondsee (Austria). For the $S$. mytilus culture, we used $0.2 \mu \mathrm{m}$ prefiltered lake water from Lake Mondsee and fed with Chlamydomonas reinhardti cells growing in a modified Woods Hole MBL medium ( $K$. O. Rothhaupt pers. comm.). Cell dimensions of each species were measured from cells fixed with Lugol's solution $10.5 \%$ final conc.) and formaldehyde (3\% final conc.; Sherr et al. 1989) using bright-field microscopy. D. campylum mean cell size (mean $\pm \mathrm{SD}$ ) was $53 \pm 6 \times 24 \pm$ 
$3 \mu \mathrm{m}$ and a cell volume of $16000 \mu \mathrm{m}^{3}$ was calculated (n $=300$ ). $P$. caudatum had a mean cell size of $202 \pm 3$ $\times 60 \pm 6 \mu \mathrm{m}$, corresponding to a cell volume of $380800 \mu^{3}(n=120)$. The mean cell size of $S$. mytilus was $141 \pm 21 \times 50 \pm 7 \mu \mathrm{m}$ with a mean volume of $185000 \mathrm{\mu m}^{3}(\mathrm{n}=160)$.

Origin of the detrital material. The green algae Monoraphidium minutum and Scenedesmus acutus and the diatom Cyclotella meneghiniana were grown in a modified Woods Hole MBL medium in a chemostat system under constant conditions (temperature $20^{\circ} \mathrm{C}$, continuous light). Cultures of the algae were kindly provided by K. O. Rothhaupt (Max Planck Institute of Limnology, Plön, Germany). Copepods (Cyclops abyssorum praealpinus) were collected by net from Lake Mondsee in February 1994. Living animals were isolated in a light trap according to Behrendt \& Krocker (1990). Leaves of the macrophyte Elodea canadensis, dry leaves of the copper beech Fagus sylvatica and fresh grass stalks of Poa annua were collected in the Lake Mondsee area in February 1994. Plants were cut into small pieces before staining. C. a. praealpinus, C. meneghiniana, E. canadensis, M. minutum and $S$. acutus were considered to represent autochthonous material and $F$. sylvatica and $P$. annua allochthonous material.

Staining procedure. The organic material was fluorescently labeled by a slightly modified method for the staining of bacteria described by Sherr et al. (1987) with 5-(4,6-dichlorotriazin-2-yl)aminofluorescein (DTAF, Sigma). Before staining, each type of organic material was washed and centrifuged. Staining time was $6 \mathrm{~h}$ at a temperature of $45^{\circ} \mathrm{C}$ and $0.25 \mathrm{mg}$ of DTAF was added to $1 \mathrm{ml}$ suspension of each type of organic matter. For storage the labeled material was frozen in small plastic vials. For each experiment the thawed fluorescently labeled material was homogenized for 2 to 3 min (Ultraturrax homogeniser) and sonicated ( 3 short pulses with maximal intensity) to produce fluorescently labeled detritus (FLD) with an equivalent spherical diameter (ESD) of 0.2 to $20 \mu \mathrm{m}$. Particle counting was done by filtering 0.5 to $1 \mathrm{ml}$ of the feeding suspension on a black polycarbonate filter (Nucleopore-Costar) with a pore size of $0.2 \mu \mathrm{m}$. At least 200 particles were counted by epifluorescence microscopy with a Zeiss Axioplan under blue excitation [excitation filter (BP) 450 to $490 \mathrm{~nm}$, beamsplitter (FT) $510 \mathrm{~nm}$, barrier filter (LP) $520 \mathrm{~nm}$ ). The size of the particles was measured with an ocular micrometer. In one experiment an automatic image analysis system (LUCIA M, Nikon) was used to determine size distributions of 6 different types of FLD. In addition, 0.5 to $1 \mathrm{ml}$ of each feeding suspension was counted by bright-field microscopy using small settling chambers to control the ratio of stained to unstained particles.
Determination of FLD uptake. Ciliates of the species Dexiostoma campylum and Paramecium caudatum show a strong negative gravitaxis. Thus they could be separated from bacteria by upward migration into sterile medium through cotton wool (over 4 to 6 h). During this time ciliates had to live in a nearly food-free medium. Therefore animals were most probably starved at the beginning of the experiments. Living ciliates of the Stylonychia mytilus complex were collected under the microscope using a micropipette and transferred into $0.2 \mu \mathrm{m}$ prefiltered lake water to separate ciliates from their food organisms. Ciliates were kept in this food-free medium for $2 \mathrm{~h}$ before we started the experiments. A $0.5 \mathrm{ml}$ volume of the cleaned $D$. campylum ( $\sim 3500$ cells) or P. caudatum ( 500 cells) ciliate culture was added in 4 parallels to $2 \mathrm{ml}$ plastic vials mounted on a rotation wheel ( $1 \mathrm{rpm}$ ) to avoid settling of food particles. After 15 min the experiment was started by adding $1 \mathrm{ml}$ of the prepared feeding suspension. In the experiments with $S$. mytilus, $3 \mathrm{ml}$ of feeding suspension was added to $2 \mathrm{ml}(\sim 40$ cells) of the ciliate culture. For both single point and time course experiments, we prepared 4 parallel vials for each uptake measurement. To stop feeding, ciliates were fixed with Lugol's solution $(0.5 \%$ final conc.) followed by immediate addition of formaldehyde $(3 \%$ final conc.; Sherr et al. 1989). A part of the sample (300 to $500 \mu \mathrm{l})$ was filtered on a $0.8 \mu \mathrm{m}$ pore size black polycarbonate filter (Nucleopore-Costar). Fixed S. mytilus cells were collected under the microscope using a micropipette and placed on the filter. Filters were washed 3 times with 5 to $10 \mathrm{ml} 0.2 \mu \mathrm{m}$ prefiltered tap water. The ciliates were stained with 4',6-diamidino-2phenylindole (DAPI, Merck) and the filter was mounted with silicon oil (for gas chromatography, Merck) between a slide and a coverslip. A total of 50 (D. campylum, P. caudatum) or 25 (S. mytilus) ciliates per sample were counted under UV excitation (BP 365 . FT 395, LP 397) and sizes of ingested particles were measured with an ocular micrometer under blue excitation at a magnification of 500 to $1250 \times$. Uptake selectivity for different size classes of FLD was calculated according to Jacobs (1974):

$$
D=\frac{r-p}{r+p-2 r p}
$$

where $D$ is a selectivity index (relative difference in uptake), $r$ is the proportion of a particular food component ingested by the animal, and $p$ is the proportion of this component in the food suspension. When $D=0$ there is no preference for this food type. Selective uptake of a food component is reflected in a $D$-value between 0 and +1 . $D$-values between 0 and -1 indicate negative selection of a food type with respect to total available food. 


\section{RESULTS}

\section{Characteristics of the fluorescently labeled detrilus (FLD)}

In our preliminary experiments we noticed differences between the various FLD suspensions with respect to the shape of the particles, the intensity of the fluorescence and the ratio of stained (50 to $80 \%$ ) to unstained ( 20 to $50 \%$ ) particles within the food suspensions. Therefore we observed in our first experiment only the visible uptake of 6 different types of detritus but were not able to give a quantification of the total ingestion. For another experiment we chose the Cyclops abyssorum praealpinus FLD because of its larger size range $(0.2$ to $15.4 \mu \mathrm{m} \mathrm{ESD})$ and its relatively constant ratio of about $80 \%$ stained to $20 \%$ unstained particles. In the last exneriment the Scenedesmus acutus FLD was chosen as model detritus whereby nearly $95 \%$ of the particles were stained. By using this type of FLD a first quantification of the uptake of detritus was possible.

\section{Ingestion of six different types of detritus by Dexios- toma campylum and Paramecium caudatum}

The size distribution of the offered suspensions was similar for all types of FLD with maximum abundances of particles in the smallest size class (0.2 to $3 \mu \mathrm{m}$ ESD). An exception was the food suspension of Monoraphidium minutum detritus (Fig. 2) in which the applied method for disrupting the cells was not effective. Total food concentrations (consisting of stained and unstained material) ranged from 0.4 to $2.3 \times 10^{6}$ particles $\mathrm{ml}^{-1}$ and the ratio of stained to unstained particles was not constant (see above). FLD uptake was described as the percentage of examined ciliates with ingested FLD particles after a feeding period of $15 \mathrm{~min}$ (Fig. 3a). In addition the numbers of vacuoles with at least 1 ingested FLD particle were counted (Fig. 3b). Both species consumed all types of detritus irrespective of the origin of the material. Generally Paramecium caudatum showed higher percentages of cells with ingested FLD and higher numbers of vacuoles containing FLD. This may be due to the larger cell size of $P$. caudatum in comparison to Dexiostoma campylum. Lower percentages of $D$. campylum cells with incorporated $M$. minutum FLD may be caused by high abundances of particles $>3 \mu \mathrm{m}$ ESD in this food suspension which were not consumed by $D$. campylum (see below).

\section{Comparison of the feeding behaviour of Dexiostoma campylum and ciliates of the Stylonychia mytilus complex}

Dexiostoma campylum is known as a typical bacterivorous ciliate (Laybourn \& Stewart 1975, Taylor \& Berger 1976). Stylonychia mytilus is considered as a typical omnivorous species (Pfister \& Arndt 1995). Cyclops abyssorum praealpinus FLD was used for these experiments because this detritus consisted of a broad size spectrum of particles ranging from $<0.4$ to $15.4 \mu \mathrm{m}$ ESD. Nine size classes were created and the frequency of each size class to the total FLD number was determined (Fig. 4a). After 15 min ingestion time, ciliates were fixed and the ingested FLD particles were sized using an ocular micrometer. For each size class we calculated the ratio of ingested to totally available particles. Using Jacobs' (1974) Selectivity Index,

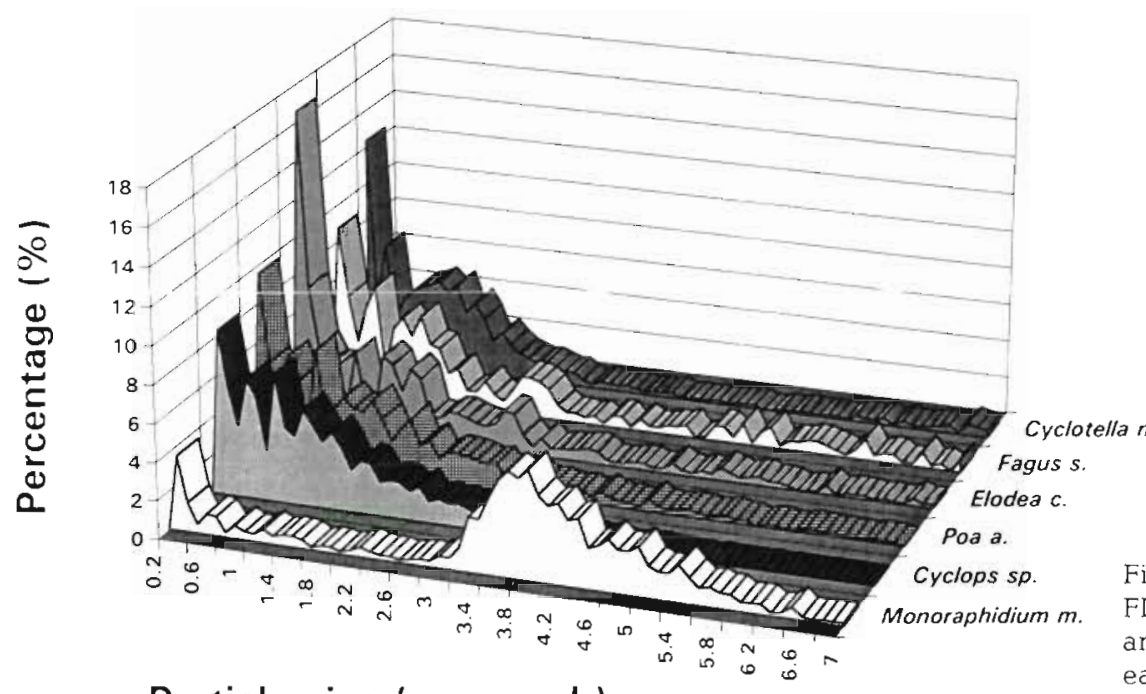

Particle size ( $\mu \mathrm{m}$ e.s.d.)
Fig. 2. Size spectrum of 6 different kinds of FLD particles measured by automatic image analysis. The relative contribution $(\%)$ of each size class to the total number of every kind of detritus is shown 


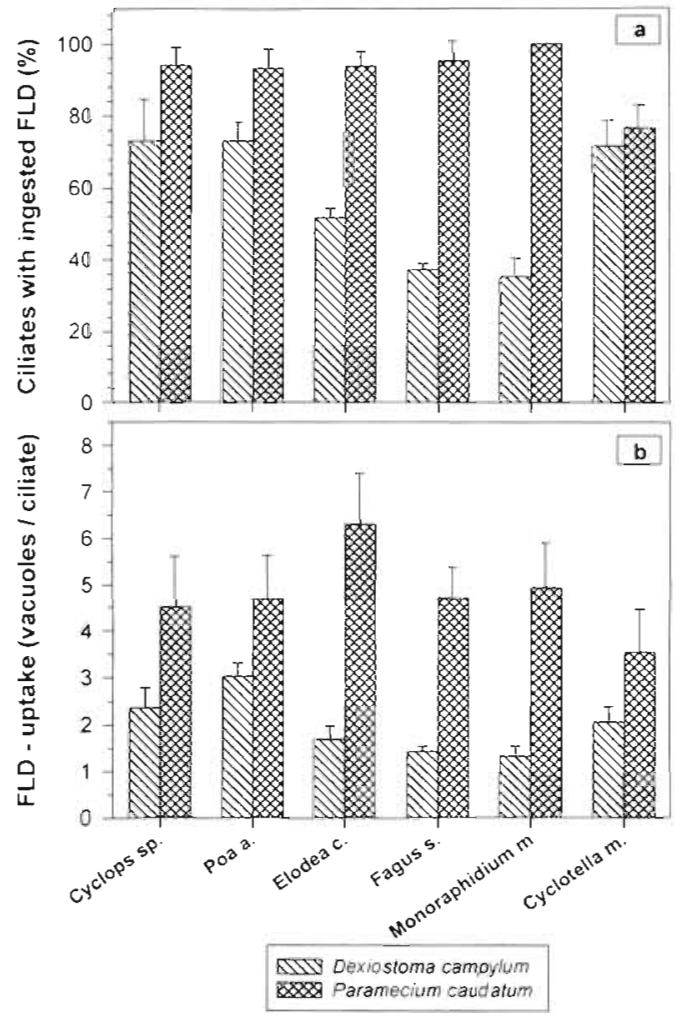

Fig. 3. Dexiostoma campylum and Paramecium caudatum. (a) Percentage of individuals with ingested FLD particles (mean of the 4 parallel vials $+\mathrm{SD}$ ). (b) Numbers of vacuoles with at least 1 ingested FLD particle per ciliate (mean of the 4 parallel vials + SD)

D. campylum was found to prefer particles in the size range 0.8 to $1.5 \mu \mathrm{m}$ whereas $S$. mytilus did not ingest particles smaller than $1.5 \mu \mathrm{m}$ (Fig. 4b). There was a clear separation of the food size niches of both species

\section{Time series of FLD uptake by Dexiostoma campylum using Scenedesmus acutus FLD}

The feeding suspension consisted of FLD particles with an ESD of 0.2 to $1.3 \mu \mathrm{m}$. A particle concentration of $9.7 \times 10^{5}$ particles $\mathrm{ml}^{-1}$ corresponded to a total detri-

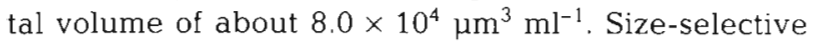
feeding was examined in the course of $20 \mathrm{~min}$. There was already a reduction of FLD uptake after $5 \mathrm{~min}$. The ingestion rate was approximately constant from 0 to 5 min and from 5 to 20 min (Fig. 5). Therefore 2 linear regressions were calculated. By the first regression ( 0 to $5 \mathrm{~min}$ ) an uptake rate of 39.5 particles ciliate ${ }^{-1} \mathrm{~h}^{-1}$ and a clearance rate of $40.7 \mathrm{nl}$ ciliate ${ }^{-1} \mathrm{~h}^{-1}$ were determined. A cell volume-specific clearance rate (VSCR) of $2.5 \times 10^{3} \mathrm{~h}^{-1}$ was calculated. From the second regres-
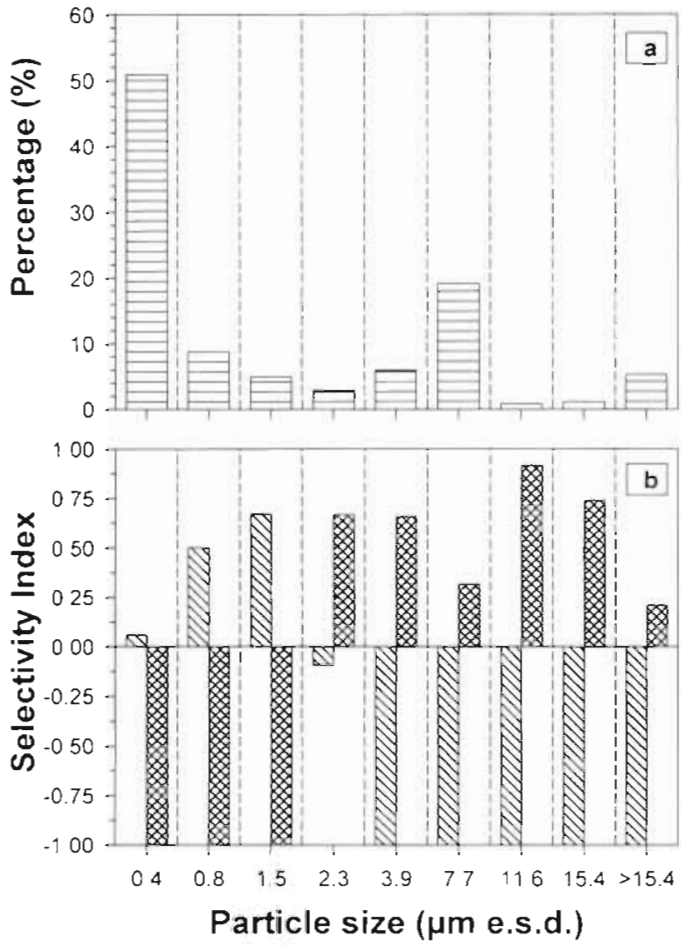

$\rightleftharpoons$ Particles (Cyclops FLD) SIII Dexiostoma campylum Stylonychia mytilus complex

Fig. 4. (a) Size spectrum of FLD particles obtained from homogenized, DTAF-stained copepods Cyclops abyssorum praealpinus. The relative contribution (\%) of each size class to the total abundance is shown. (b) Comparison of the sizeselective feeding of Dexiostoma campylum and a ciliate clone of the Stylonychia mytilus complex offered C. a. praealpinus FLD

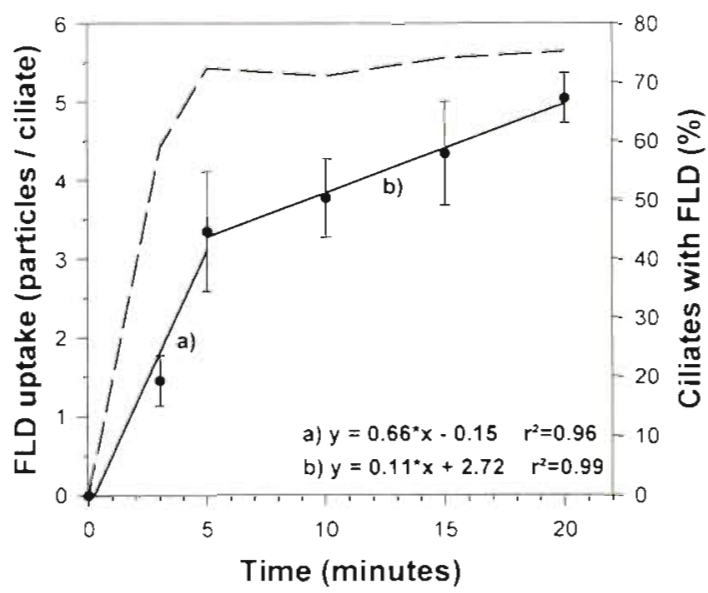

Fig. 5. Time-dependent uptake of Scenedesmus acutus FLD particles by Dexiostoma campylum ( $\bullet$, mean of the 4 parallel vials \pm SD). Two regression lines were calculated: (a) 0 to $5 \mathrm{~min}$, (b) 5 to $20 \mathrm{~min}$. Particle uptake $(y)$ was assumed to be a function of time $(x)$. (- - ) Percentage of examined ciliates with ingested particles 


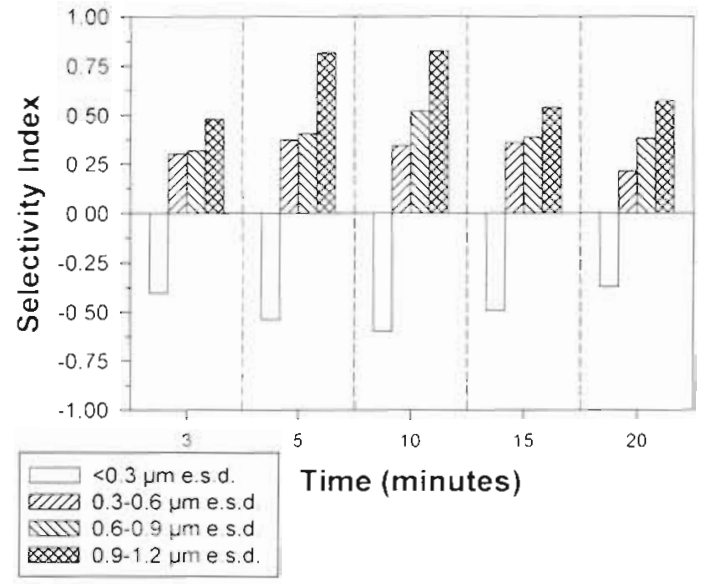

Fig. 6. Size-selective feeding behaviour of Dexiostoma campylum on Scenedesmus acutus FLD particles during the time course experiment ( 0 to $20 \mathrm{~min}$ )

sion (5 to $20 \mathrm{~min}$ ), we calculated an uptake rate of 9.3 particles ciliate ${ }^{-1} \mathrm{~h}^{-1}$ and a clearance rate of $9.6 \mathrm{nl}$ ciliate $^{-1} \mathrm{~h}^{-1}$ (VSCR $\left.=6 \times 10^{2} \mathrm{~h}^{-1}\right)$. The percentage of ciliates containing FLD particles remained fairly constant after $5 \mathrm{~min}$ of the experiment (Fig. 5). We noted a strong uptake preference for the largest particle size class $(0.9$ to $1.3 \mu \mathrm{m}$ ESD). Selectivity did not significantly change with time (Fig. 6).

\section{DISCUSSION}

Detritivory or detritivory as a part of omnivory has often been reported to occur among planktonic protozoa, especially ciliates (Kahl 1930-1935, Sandon 1932, Gast 1985, Fenchel 1987, Sherr \& Sherr 1992). Its significance as a food source, however, is not well understood, for many reasons. Firstly, there is a problem with the definition of the term detritus, and there is no reliable method to quantify dead organic matter in aquatic energy fluxes (Lenz 1972, Melack 1985). Generally, the measurement of uptake rates of detrital particles by ciliates is even more difficult. Nevertheless, there are several studies that demonstrate the uptake and assimilation of detritus by cladocerans (Naumann 1918, Rod-

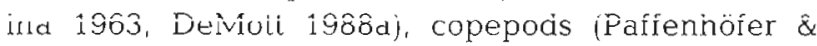
Knowles 1979, Roman 1984, DeMott 1988b) and rotifers (Starkweather \& Bogdan 1980). Ciliates, however, have seldom been examined with regard to the type and quantity of detritus they are able to consume, although not only size-selective feeding of filter-feeding ciliates has been shown (Fenchel 1980, 1986), but also selectivity for surface, shape or taste (e.g. Sanders 1988, Verity 1991). To consider these potentially important qualities of detritus, we offered several model types of FLD rather than using inert particles
(FP), microspheres or carbon particles. Of course, the artificial destruction of the organic material is a simplification of the complex decomposition in vivo (see Fig. 1). However, simple destruction of pelagic organisms into fine particulate detritus can play an important role in the pelagic environment during sloppy feeding and excretion of crustaceans, which provide significant amounts of easily digestible fractions of phytoplankton (Lampert 1978, Olsen et al. 1986).

All 3 ciliate species were found to consume the offered detrital particles. We can assume that the chosen ciliate species were representative organisms for detritivory, because they are ubiquitous in lakes and rivers and prefer nutrient-rich conditions (Foissner et al. 1994). Therefore, especially at seasonally higher concentrations of natural detrital particles (Middelboe \& Søndergaard 1995) or during eutrophication, certain ciliate species are likely to profit from this additional food source. The percentage of Dexiostoma campylum individuals which consumed detritus of Fagus sylvatica and Monoraphidium minutum was lower than the fraction of individuals feeding upon detritus of Cyclops abyssorum praealpinus, Cyclotella meneghiniana, Elodea canadensis and Poa annua (Fig. 3a). The lower percentage of $D$. campylum cells incorporating $M$. minutum FLD particles may be caused by size-selective feeding. This kind of detritus had a size distribution different from that of all other kinds of offered detritus, with a predominance of large particles (4 to $5 \mu \mathrm{m}$; see Fig. 2). D. campylum is known from the literature to feed effectively on very small particles (Fenchel 1980). Our results also showed that D. campylum did not consume particles larger than $2.3 \mu \mathrm{m}$ (Fig. 4b). But we do not know the reasons for the low uptake rates of F. sylvatica FLD. On the other hand, we did not find an explanation for the nearly constant feeding behaviour of Paramecium caudatum irrespective of food type and the size distributions of the different kinds of detritus (Fig. 3a). Ciliates of the Stylonychia mytilus complex, in contrast, only consumed particles larger than $1.5 \mu \mathrm{m}$ (Fig. 4b). This species is known as a typical omnivore (Pfister \& Arndt 1995) Thus not only the lower consumable size but also an upper size limit may contribute to the food niche separation of coexisting suspension-feeding ciliates.

The time course experiment with Dexiostoma campylum revealed 2 uptake rates of detrital particles (Fig. 5). Though ciliates had been acclimated to the experimental vials, they were perhaps still stressed at the beginning of the experiment. This may have caused an arbitrary ingestion behaviour (Choi 1994). Massana et al. (1994) noticed an acclimation time of at least $2 \mathrm{~h}$ before ciliates showed regular feeding behaviour again. However this does not explain the observed shift, which had already occurred after $10 \mathrm{~min}$. Fur- 
thermore, a stress effect should result in lower rather than higher ingestion rates at the beginning of an experiment (Massana et al. 1994). Another explanation may be the establishment of an equilibrium between uptake and egestion after $10 \mathrm{~min}$. On the other hand, there was no atypical size-selective feeding noticed over the 20 min (Fig 6). Therefore the higher uptake rates within the first 5 min were most likely due to a starvation effect as $D$. campylum had to live in a nearly food-free medium for 4 to $6 \mathrm{~h}$ prior to the experiment (see above). A comparison of the observed uptake rates with published feeding rates of $D$. campylum (Table 1) showed that in most studies significantly higher food concentrations (bacteria or latex beads) were offered at lower ciliate abundances (Laybourn \& Stewart 1975, Fenchel 1980). Similar low food concentrations were used by Sanders (1988) for the scuticociliate Cyclidium sp., for which an uptake rate of 23 or 25 microspheres ciliate ${ }^{-1} \mathrm{~h}^{-1}$ at a food concentration of 4.8 or $5.6 \times 10^{5}$ microspheres $\mathrm{ml}^{-1}$ was observed. This value is comparable to uptake rates observed during our experiments. In general the concentrations of detrital particles used in our experiments seem to be low in comparison with expected concentrations in nature. Further investigations should pay attention to this fact and perhaps use even higher abundances of detrital particles, which exceed bacterial numbers commonly determined in nature.

Since the discovery of high abundances of submicrometre particulate detritus (Koike et al. 1990, Middelboe \& Søndergaard 1995) there has been an open question about the fate of this organic source in pelagic ecosystems. Our results suggest that this size class of detritus should also be considered as an additional food source for ciliates (and probably other protists) besides bacteria and other picoplankton. Living and dead organic matter are probably ingested simultaneously in the form of colonized particles. Even if consumed detrital particles are only partly digested, suspensionfeeding ciliates could transform them via excretion with respect to size, shape, coating or aggregation behaviour (cf. Stoecker 1984, Elbrächter 1991). This may contribute significantly to particle transformation and metabolism in pelagic and benthic environments.

Another question concerns the effects of different concentrations of detrital particles on the feeding behaviour of ciliates. Roman (1984) reported a higher feeding activity of copepods fed with diatoms and detritus than those fed only with diatoms; however, a diet consisting only of detritus caused a reduction of the growth rate and/or the reproduction rate (Rodina 1963). Further studies are required to investigate if similar effects can also be observed for suspensionfeeding ciliates. Moreover there is a need to determine the nutritive value of these detrital particles (e.g. car-

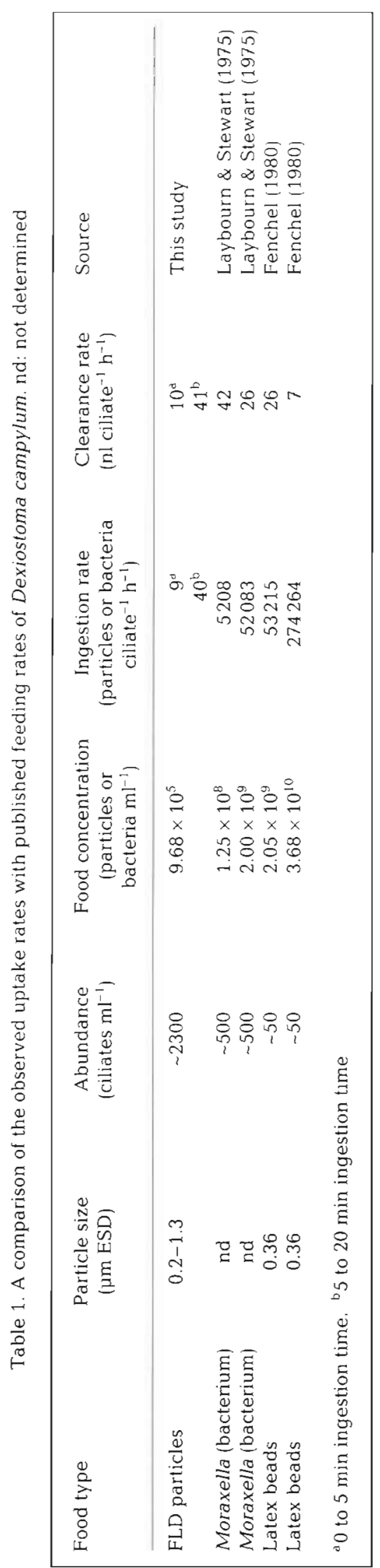


bon:volume, carbon:nitrogen ratios) and the assimilation efficiency of protozod feeding on detritus. Our experiments give new evidence that detrital particles of various origins can be directly incorporated into microbial food webs by suspension-feeding ciliates. This indicates that the division into detritus and grazing food chain is partially artificial and the fate of detritus is more complex than generally considered (Fig. 1).

Acknowledgements. We thank A. Alfreider, J. Pernthaler, R. Psenner and S. Wickham for constructive criticism and discussion. We also thank our colleagues at the Institute of Limnology (Mondsee, Austria) for help. Last but not least we thank 3 anonymous reviewers for their useful comments on an earlier version of the manuscript.

\section{LITERATURE CITED}

Behrendt $H_{1}$ Krocker $M$ (1990) A method for the senaration of zooplankton in high eutrophic water bodies. Limnologica 20:79-81

Choi JW (1994) The dynamic nature of protistan ingestion reponse to prey abundance. J Euk Microbiol 41:137-146

DeMott WR (1988a) Discrimination between algae and detritus by freshwater and marine zooplankton. Bull Mar Sci 43:486-499

DeMott WR (1988b) Discrimination between algae and artificial particles by freshwater and marine copepods. Limnol Oceanogr 33:397-408

Elbrächter M (1991) Faeces production by dinoflagellates and other small flagellates. Mar Microb Food Webs 5:189-204

Fenchel $T$ (1970) Studies on the decomposition of organic detritus derived from the turtle grass Thalassia testudinum. Limnol Oceanogr 15:14-20

Fenchel T (1980) Suspension feeding in ciliated protozoa: structure and function of feeding organelles. Arch Protistenkd 123:239-260

Fenchel T (1986) Protozoan filter feeding. Prog Protistol 1: $65-113$

Fenchel T (1987) Ecology of protozoa: the biology of free-living phagotrophic protists. Science Tech Publishers, Madison and Springer-Verlag, Berlin

Foissner W, Berger H, Kohmann F (1994) Taxonomische und ökologische Revision der Ciliaten des Saprobiensystems - Band 3: Hymenostomata, Prostomatida, Nassulida. Informationsberichte des Bayerischen Landesamtes für Wasserwirtschaft, München, Heft 1/94

Ganner B, Foissner W (1989) Taxonomy and ecology of some ciliates (Protozoa, Ciliophora) of the saprobic system. III. Revision of the genera Colpidium and Dexiostoma and establishment of a new genus, Paracolpidium nov. gen. Hydrobioiogia 182:181-2i8

Gast V (1985) Bacteria as a food source for microzooplankton in the Schlei Fjord and Baltic Sea with special reference to ciliates. Mar Ecol Prog Ser 22:107-120

Georgi F (1985) Verteilung und Beschaffenheit des Sestons in inneren Küstengewässern der DDR (Darß-Zingster Boddengewässer) sowie der westlichen und mittleren Ostsee unter besonderer Berücksichtigung der Wasseraustauschprozesse zwischen beiden Systemen. Beitr Meereskde 52 $35-48$

González JM, Suttle CA (1993) Grazing by marine nanoflagellates on viruses and virus-sized particles: ingestion and digestion. Mar Ecol Prog Ser 94:1-10
Grossart HP, Simon M (1993) Limnetic macroscopic organic aggregates (lake snow): occurrence, characteristics, and microbial dynamics in Lake Constance. Limnol Oceanogr 38:532-546

Jacobs J (1974) Quantitative measurement of food selection (a modification of the forage ratio and Ivlev's electivity index). Oecologia 14:413-417

Johnson BD, Cooke RC (1980) Organic particle and aggregate formation resulting from the dissolution of bubbles in seawater. Limnol Oceanogr 25:653-661

Kahl KH (1930-1935) Urtiere oder Protozoa 1. Wimpertiere oder Ciliata (Infusoria). In: Dahl F (ed) Die Tierwelt Deutschlands $(18,21,25,30\}$. Fischer, Jena

Kepkay PE (1994) Particle aggregation and the biological reactivity of colloids. Mar Ecol Prog Ser 109:293-304

Kersting K, Holterman W (1973) The feeding behaviour of Daphnia magna studied with the coulter counter. Verh Int Verein Limnol 18:1434-1440

Koike I, Shigemitsu H, Kazuki T, Kazuhiro K (1990) Role of sub-micrometre particles in the ocean. Nature 345: $242-244$

Lampert W (1978) Release of dissolved organic carbon by grazing zooplankton. Limnol Oceanogr 23:831-834

Laybourn JEM, Stewart JM (1975) Studies on consumption and growth in the ciliate Colpidium campylum Stokes. J Anim Ecol 44:165-174

Lenz $\mathrm{J}$ (1972) The size distribution of particles in marine detritus. Mem Ist Ital Idrobiol 29(Suppl):17-35

Marchant HJ, Scott FJ (1993) Uptake of sub-micrometre particles and dissolved organic material by Antarctic choanoflagellates. Mar Ecol Prog Ser 92:59-64

Massana R, Stumm CK, Pedrós-Alió C (1994) Effects of temperature, sulfide, and food abundance on growth and feeding of anaerobic ciliates. Appl Environ Microbiol 60 : $1317-1324$

Melack JM (1985) Interactions of detrital particulates and plankton. Hydrobiologia 125:209-220

Middelboe M, Søndergaard M (1995) Concentration and bacterial utilization of submicron particles and dissolved organic carbon in lakes and a coastal area. Arch Hydrobio] $133: 129-147$

Naumann E (1918) Über die natüliche Nahrung des limnischen Zooplanktons. Lunds Universitets Årskrift NF Avd 2, Bd 14, Nr 31

Olsen Y, Varum KM, Jensen A (1986) Some characteristics of the carbon compounds released by Daphnia. J Plankton Res 8:505-517

Paffenhöfer GA, Knowles SC (1979) Ecological implications of fecal pellet size, production and consumption by copepods. J Mar Res 37:35-49

Passow U, Alldredge AL (1994) Distribution, size and bacterial colonization of transparent exopolymer particles (TEP) in the ocean. Mar Ecol Prog Ser 113:185-198

Pedrós-Alió C, Brock TD (1983) The importance of attach-

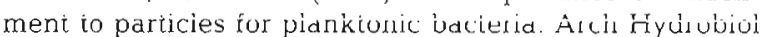
98:354-379

Pfister $\mathrm{G}_{\text {, Arndt } H}$ (1995) Food selectivity in the hypotrich ciliate Stylonychia mytilus - an experimental approach to quantify omnivory. J Euk Microbiol 42:6A

Rodina AG (1963) Microbiology of detritus of lakes. Limnol Oceanogr 8:388-393

Roman MR (1984) Utilization of detritus by the copepod, Acartia tonsa Limnol Oceanogr 29:949-959

Sanders RW (1988) Feeding by Cyclidium sp. (Ciliophora, Scuticociliatida) on particles of different sizes and surface properties. Bull Mar Sci 43:446-457

Sandon H (1932) The food of protozoa. The Egyptian Univer- 
sity, Publications of the Faculty of Sciences No 1, Cairo

Sherr BF, Sherr EB, Fallon RD (1987) Use of monodispersed, fluorescently labeled bacteria to estimate in situ protozoan bacterivory. Appl Environ Microbiol 53:958-965

Sherr BF, Sherr EB, Pedrós-Alió C (1989) Simultaneous measurement of bacterioplankton production and protozoan bacterivory in estuarine water. Mar Ecol Prog Ser 54 $209-219$

Sherr EB (1988) Direct use of high molecular weight polysaccharide by heterotrophic flagellates. Nature 335:348-351

Sherr EB, Sherr BF (1992) Trophic roles of pelagic protists: phagotrophic flagellates as herbivores. Arch Hydrobiol Beih Ergebn Limnol 37:165-172

Silver MW, Gowing MM, Brownlee DC, Corliss JO (1984) Ciliated protozoa associated with oceanic sinking detritus. Nature 309:246-248

Søndergaard M, Middelboe M (1993) Measurements of particulate organic carbon: a note on the use of glass fiber

Responsible Subject Editor: K. Simek, Ceské Budějovice, Czech Republic
(GF/F) and Anodisc ${ }^{(6)}$ filters. Arch Hydrobiol 127:73-85

Starkweather PL, Bogdan KG (1980) Detrital feeding in natural zooplankton communities: discrimination between live and dead algal foods. Hydrobiologia 73:83-85

Stoecker DK (1984) Particle production by planktonic ciliates. Limnol Oceanogr 29:930-940

Suttle CA, Chan AM, Cottrell MT (1990) Infection of phytoplankton by viruses and reduction of primary productivity. Nature 347:467-469

Taylor WD, Berger J (1976) Growth of Colpidium campylum in monoxenic batch culture. Can J Zool 54:392-398

Tranvik LJ, Sherr EB, Sherr BF (1993) Uptake and utilization of 'colloidal DOM' by heterotrophic flagellates in seawater. Mar Ecol Prog Ser 92:301-309

Verity PG (1991) Feeding in planktonic protozoans: Evidence for non-random acquisition of prey. J Protozool 38:69-76

Wotton RS (1984) The importance of identifying the origins of microfine particles in aquatic systems. Oikos 43:217-221

Manuscript first received: October 9, 1995

Revised version accepted: December 20, 1995 